\title{
Inflammatory Periapical Cyst in the Upper Maxilla: Clinical Case Report
}

\author{
Fabiana Cristina Martinez Herrera*1, Salvador Cicco ${ }^{2}$, Laura Parra ${ }^{3}$, Inés Villegas ${ }^{4}$ and Frederick Segura Ruíz ${ }^{5}$ \\ ${ }^{1}$ General Dentist, Nor-Oriental private University “Gran Mariscal de Ayacucho”, Venezuela \\ ${ }^{2}$ General Dentist, Central University of Venezuela, Venezuela
}

${ }^{3}$ Dentist Specialist in oral surgery, Central University of Venezuela, Venezuela

${ }^{4}$ Dentist Specialist in Endodontics, Central University of Venezuela, Venezuela

${ }^{5}$ Specialist in University Teaching, Experimental University “Rómulo Gallegos", Venezuela

Submission: June 14, 2018; Published: July 13, 2018

*Corresponding author: Fabiana Cristina Martinez Herrera, General Dentist graduated in Nor-Oriental private University “Gran Mariscal de Ayacucho", Barcelona, Venezuela, Tel: +58 414-3920000; Email: fabianamartinez24@hotmail.com

\section{Abstract}

A review is made on the topic of periapical cysts in the maxilla with the aim of broadening the knowledge on this subject, due to the disorders that these can cause both aesthetic and functionally and the affectation that can produce in the Integrity of the maxillofacial component, hence the importance of adequate diagnosis and treatment.

Periapical cysts represent the majority of all maxillofacial cysts, between 57 and $87 \%$. Also called Paradental cyst, radicular, periodontal, is a small sac, with a center full of liquid or semi-solid material covered internally with epithelium and externally with fibrous connective tissue. It is presented as an inflammatory lesion of the jaws formed at the apex of the root of an erupted tooth, whose pulp is necrotic and infected being a direct sequel of an apical granuloma, has more frequency in the upper maxilla.

A clinical case of periapical cyst of inflammatory origin is presented. The 35-year-old patient is female. The panoramic radiographic technique is used and radiolucid image is observed at the antero-superior sector, where this pathology is diagnosed presumptively. Subsequently, surgical removal and sample dispatching is performed for histopathological study; it is diagnosed as periapical cyst.

Keywords: Apical cyst; Paradental cyst; Periodontal cyst; Apical cyst; Radicular cyst

\section{Introduction}

Periapical cyst, called also radicular cyst and apical periodontal cyst, is by far the most frequent type of odontogenic cyst and represents more than half of the total of the oral cysts. It appears at the apex of the root of a tooth erupted, whose pulp has been devitalized by caries or dental trauma [1], also occurs when an inflammation of the tooth pulp reaches the periapical zone, causing the formation of a granuloma. The inflammatory stimulus, not intense, but persistent causes the proliferation of epithelial remains of Malassezia, which increase in size in response to inflammation triggered by bacterial infection of the pulp or in direct response to tissue Necrotic Pulper, finally those more internal cells undergo ischemic necrosis by liquefaction and result in a central cavity (light) surrounded by viable epithelium. At the time, an osmotic gradient is established through the epithelial lining (membrane) that separates the fluids from the connective tissue from the necrotic content of the newly formed cyst $[1,2]$.

Clinically Although most periapical cysts appear at the apex of the root, adjacent to the apical orifice, they may sometimes appear in the orifice of large accessory root canals, through which the pulp inflammation and products of the Pulp necrosis may come out to form granulomas. The size of the periapical cysts is variable, but in general they measure less than $1 \mathrm{~cm}$ in diameter. Sometimes, however, the cyst may become much larger, especially in areas where several adjacent teeth in the anterior part of the mandible or maxilla have been devitalized as a result of facial trauma [3].

The existence of a radio lucid shade at the apex of a tooth may have different meanings, from non-pathological anatomical variants to malignant tumor lesions [4], so that it is not always possible to differentiate a cyst from an inflammatory apical granuloma, However, cysts are usually larger and have welldefined boundaries. Sometimes a radiopaque image appears in the periphery of the apical radio lucidity, this would indicate a local reaction of the bone or the periodontal hard lamina, compared to the pressure of the mass in growth and expansion, fact that has also been described in some granulomas Apical. This image can be erased when the cyst is over infected. High et al. [5,6]. It points out 
that this calcified peripheral profile is more evident in the residual and long patocrinia cases.

The radiographic size to be acquired by the lesion to be considered as a cyst is for some authors greater than $5 \mathrm{~mm}$. For Morse et al. [7]. The size must be greater than $10 \mathrm{~mm}$ and for Lalonde and Luebkeet. Higher [8] than 20mm. Rodríguez Roselee $\mathrm{Al}$ [9], he deduced that a periapical radiolucid image of $5 \mathrm{~mm}$ in diameter is compatible with the existence of a periapical inflammatory cyst and that in the period of one year it acquires an already consolidated size.

Histologically, most radicular cysts consist of a fibrous connective tissue and a stratified squamous epithelium of very variable thickness and structure. The morphology of its epithelium depends on the degree of inflammation and, in it, it is possible to observe areas of papillomatosis, acanthosis, spongiosis phenomena and even fragmented and eroded atrophic areas. Areas of hyperkeratinization are less frequent. Cysts often contain goblet, ciliated or Mucosecretoras cells [10].

\section{Case Report}

Female patient of 35 years of age and from Barcelona, Venezuela, of occupation housewife, denies family history and personal of importance. He goes to consult for presenting extraoral edema, chronic pain and purulent exudate through dental alveolus of the upper left incisor. It refers that the lesion has evolution 45 days approximately, presenting volume increase in the vestibular area of the anterior sector of the maxilla, receiving as treatment amoxicillin with acid clavulanic $875 \mathrm{mg} / 125 \mathrm{mg}$ and later with Vancomycin via Intravenous (unknown dose). The intraoral examination is an increase in volume in the anterior sector of the maxilla, observing the furrow bottom, the consistency with palpation is soft, covered by normal-looking mucosa and the same color of surrounding tissue. It also presents the absence of the U.D. 1.1 and 2.1.

\section{Radiographic Diagnosis}

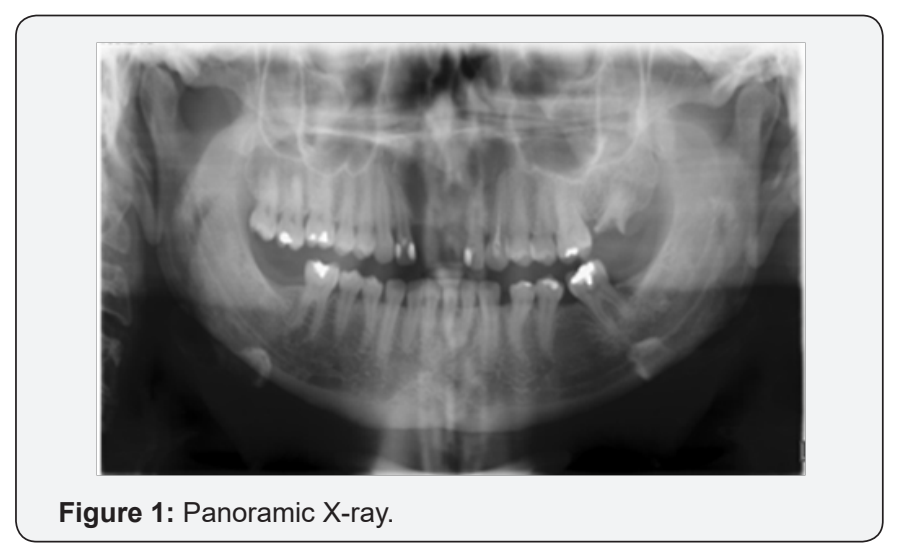

Radiographically, there is a lobular radio lucid image of precise edges covering the maxillary anterosuperior area from the U.D. 1.2 and 2.2 horizontally extending to the floor of the nasal fossa in a vertical direction, in contact with apexes of the U.D. 2.3
In addition, it is observed radio lucid image that corresponds to Alveolus of the U.D. 2.1 in intimate contact with lesion mentioned above (Figure $1 \& 2$ ).

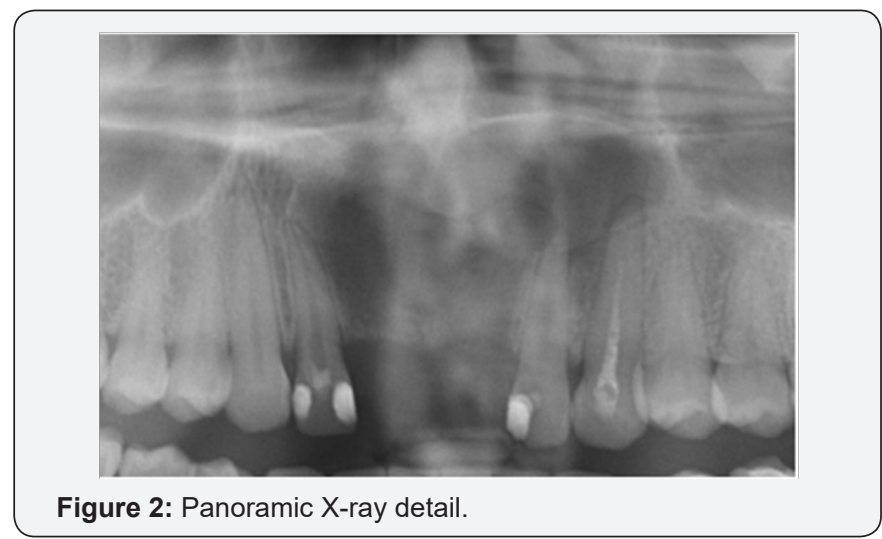

\section{Treatment Plan}

A comprehensive treatment is planned, which includes excision of the cyst.

\section{Surgical Treatment}

After a week of conducting conventional endodontics of $1.2,2.2,2.3$, surgery was performed under local anesthesia $(2 \%$ lidocaine with epinephrine 1:80000) with infraorbital technique, thus performing an incision and flap lift (due to bone loss No osteotomy was required) and thus have access to the lesion. Proceeding to perform the cyst enucleation. The complete lesion was taken to perform histopathological study (Figure 3). Borders are confronted and sutured with simple points making hemostasis with gauze.

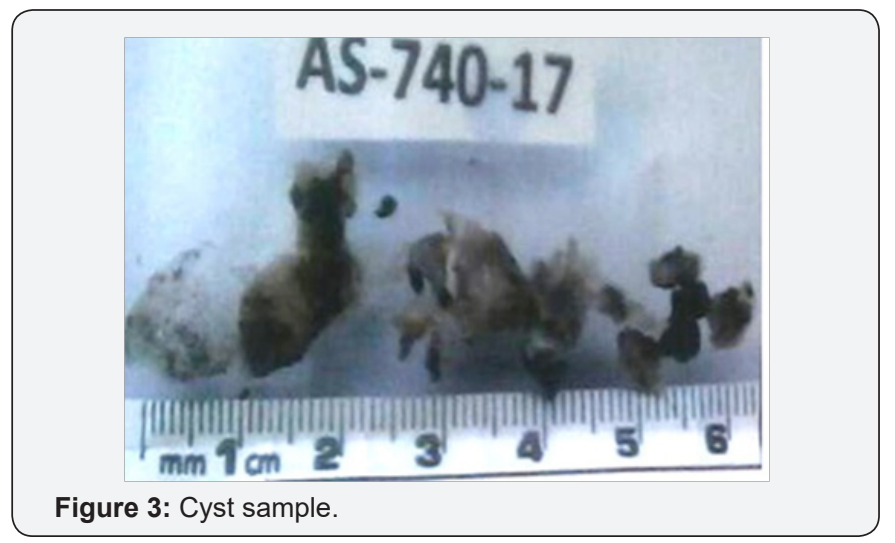

It is ordered antibiotic type amoxicillin with clavulanic acid tablets of $875 \mathrm{mg} / 125 \mathrm{mg}$ T.I.D. (every 8 hours) for seven days continuous and analgesic type Ketorolac tromethamine tablets 10mg. T.I.D. (every 8 hours) in conjunction with ibuprofen tablets $600 \mathrm{mg}$ T.I.D. (every 8 hours) for five continuous days. Both written and verbal indications and contraindications are given. On the eighth day Postsurgical control is carried out where it is observed scarring by first intension, the sutures are removed after sanitization with oxygenated water. Radiographic control is performed every month, third month and sixth month with bone scarring. 


\section{Histopathological analysis}

Histopathological analysis showed a layer of squamous epithelium, stratified, non-keratinized, with marked Acanthosis, spongiosis and exocytosis; Resting on a stroma of dense connective tissue, proliferative, which houses inflammatory foci of linfoplasmocitario predominance, abundant crystals of cholesterol, extravasated erythrocytes, hiperémicos blood vessels, mature collagen bands and Hemosiderin deposits (Figure 4). This confirms the diagnosis of inflammatory odontogenic cyst/ periapical cyst.

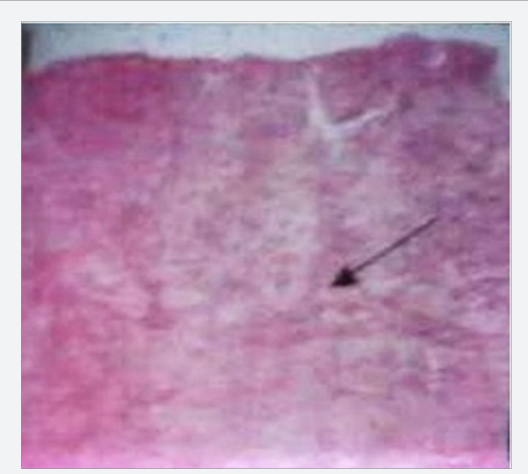

Figure 4: Cystic epithelium reactive to stromal inflammation.

\section{Discussion}

Periapical cyst occupies the first place in evidence of all maxillary cysts, representing more than half of the total oral cysts1. Although radicular cysts may affect any tooth, the Deciduous are rare. $60-80 \%$ are in the upper jaw and preferably involve the anterior teeth [11].

The general practitioner must make an excellent clinical history of admission, always use the different diagnostic methods to establish a proper treatment plan for pathological lesions in both children and adults.

\section{Conclusion}

The case turned out to be a benign lesion, but it is a fact that the need to raise awareness about the need to undergo dental control with some periodicity is a highlight. It is important to emphasize that although the incidence of this lesion is low, a thorough clinical evaluation is necessary. It is an absolute requirement that all tissues coming from the periapical cysts should undergo a histopathological examination, for a proper definitive diagnosis and handling of lesions, since there are other pathologies that can be presented in a similar way. Radiological studies are not determinant in the diagnosis of lesions at apical level, since the factors such as shape and size are not pathognomonic signs. These lesions are usually asymptomatic, so their early detection will be given less often.

\section{References}

1. Saap J, Eversole L, Wysocki, G (2006) Patología Oral y Maxilofacial Contemporánea ( $\left.2^{\text {nd }} e d n\right)$, España: Editorial Elsevier, Netherlands.

2. Raspall G (2001) Cirugía maxilofacial: patología quirúrgica de la cara, boca, cabeza y cuello. ( $1^{\text {st }}$ edn), España: Editorial Medica Panamericana Spain.

3. Vergara C, Ojeda M, Le Franc JP (2010) Manejo Clínico del Quiste Periapical. Revista de la Facultad de Ciencias de la Salud 7(2).

4. Raspall G (2007) Cirugía oral eimplantología. (2 $2^{\text {nd }}$ Edn), Buenos Aires: Editorial medica panamericana, Spain.

5. High AS, Hisrchmann PN (1988) Symptomatic residual radicular cysts. J Oral Pathol 17: 70-72.

6. High AS , Hirschmann PN (1986) Agechange in residual radicular cysts. J Oral Pathol 15(10): 524-528.

7. Morse DR, Patnik J, Schacterler G (1973) Electrophoreticdifferentiation of radicular cysts and granulomas. Oral Surg 35(2): 249-264.

8. Ernest RL, Luebke RG (1968) The frequency and distribution of periapical cysts and granulomas. Oral Surg 25(6): 861-868.

9. Rodríguez RE (1991) Aportaciones al conocimiento de la histogénesis de los quistes odontogénicos inflamatorios a través de las técnicas enzimáticas e inmunohistoquímicas (Tesis doctoral) Oviedo. Universidad de Oviedo.

10. García RA, Bujaldón DAL, Rodríguez AA (2015) Lesiones periapicales: diagnóstico y tratamiento. Av Odontoestomatol 31(1): 31-42.

11. Suarez C, Gil-Carcedo L, Medina J, Ortega P, Trinidad J (2008) Tratado de Otorrinolaringología y Cirugía de Cabeza y Cuello: Cirugía Oncológica de cabeza y cuello y de la base de cráneo $\left(2^{\text {nd }}\right.$ Edn) Buenos Aires: Editorial Medica Panamericana 10: 237.

\section{Your next submission with Juniper Publishers will reach you the below assets}

- Quality Editorial service

- Swift Peer Review

- Reprints availability

- E-prints Service

- Manuscript Podcast for convenient understanding

- Global attainment for your research

- Manuscript accessibility in different formats

( Pdf, E-pub, Full Text, Audio)

- Unceasing customer service

Track the below URL for one-step submission https://juniperpublishers.com/online-submission.php 